\title{
The accuracy of intake estimation based on the use of alkane controlled-release capsules and faeces grab sampling in cows
}

\author{
Nigel R. BerRy, Martin R.L. SchEedER, Franz SutTER, \\ Thomas F. KRÖBER, Michael KREUZER* \\ Institute of Animal Sciences, ETH Zurich, ETH Centre/LFW, 8092 Zurich, Switzerland
}

(Received 15 April 1999; accepted 25 November 1999)

\begin{abstract}
Alkanes are digesta markers for use as a research tool giving the opportunity to estimate feed intake and digestibility in vivo. The development of intra-ruminal controlled-release capsules (CRC) offers a practical method of dosing even-chain alkanes and may give less diurnal variability of marker excretion improving the validity of grab-faecal sampling. This was tested in the present study by total faeces collection in four cows for 7 days. Dry matter intake was $10.4 \mathrm{~kg}$ forages and $10.4 \mathrm{~kg}$ concentrate (diet 1 ) and $15.1 \mathrm{~kg}$ forage (diet 2). The recovery (proportion of dosed or dietary alkane intake found in faeces) of $\mathrm{C}_{31}$ was lower than that of $\mathrm{C}_{32}$ and consequently underestimated intake. $\mathrm{C}_{33}$ and $\mathrm{C}_{32}$ had similar recoveries giving accurate intake estimates from pooled samples from total daily faecal collections and also from grab samples taken at $6.30 \mathrm{a} . \mathrm{m}$. The study confirms that a single injection for gas chromatography is sufficient. Alkane CRC are concluded to be an accurate method for estimating forage intake of cows consuming diets with or without concentrate when spot sampling of faeces is conducted over 7 days and only moderately less precise when sampling over 5 days.
\end{abstract}

alkane / controlled-release capsule / feed intake / forage / cow

Résumé - Précision de l'ingestion estimée par des capsules à libération contrôlée d'alcanes chez les vaches à partir d'échantillons de fèces. Les alcanes sont en passe de devenir des marqueurs prometteurs, en tant qu'outil pour estimer l'ingestion in vivo. Des alcanes à chaînes paires administrés dans le rumen sont comparés à des alcanes à chaînes impaires naturellement présents dans la cire cuticulaire des végétaux ingérés par le ruminant. Le développement de capsules intra-ruminales à libération contrôlée (CRC) facilite la distribution à l'animal d'alcanes à chaînes paires et pourrait ainsi diminuer la variation journalière de l'excrétion du marqueur en augmentant la validité des échantillons de fèces. C'est ce qui a été testé ici, en récoltant en totalité les excrétions fécales de 4 vaches pendant une semaine. Les quantités ingérées étaient de 10,4 kg de MS pour le fourrage et de 10,4 kg de MS

* Correspondence and reprints

Tel.: (41) 1632 5972; fax: (41) 1632 1128; e-mail: michael.kreuzer@inw.agrl.ethz.ch 
pour le concentré (ration 1) et $15,1 \mathrm{~kg}$ de MS pour le fourrage (ration 2). Le taux de récupération du $\mathrm{C}_{31}$ était inférieur à celui du $\mathrm{C}_{32}$, conduisant donc à une sous-estimation de l'ingestion. Par contre, les taux de récupération du $\mathrm{C}_{33}$ et $\mathrm{C}_{32}$ étaient presque égaux, et donnaient des estimations précises avec les échantillons de la collecte quotidienne totale des fèces, mais aussi avec les prélèvements rectaux à 06:30 h. La prise d'échantillons de fèces devrait se faire pendant chacun des 7 jours de la durée de collecte recommandée, les estimations étant un peu moins précises lorsque la collecte est sur 5 jours. La libération de marqueur à partir de la capsule avait cessé au bout de 5 semaines. En conclusion, les alcanes administrés par CRC sont considérés comme une méthode précise pour estimer l'ingestion chez des vaches recevant des rations avec ou sans concentré.

alcane / capsule à libération contrôlée / ingestion / fourrage / vache

\section{INTRODUCTION}

The use of $n$-alkanes for the estimation of herbage intake in ruminants has attracted increasing attention [4]. Traditional marker methods such as chromium oxide combined with in vitro digestibility techniques may give less accurate estimates of intake owing especially to the variation surrounding digestibility coefficients and the fact that a single value of digestibility is often used for a group of animals [4]. Alkanes are present naturally in plant cuticular waxes, they are non-toxic and are principally indigestible. This offers the opportunity to estimate feed intake and digestibility in vivo for each research animal. The relative and not the absolute recovery of odd-chain internal (plant wax) and even-chain external (dosed) alkane markers are compared using ratios within formulae [20] giving intake estimates. Difficulties arise from the labour requirement to hand-manufacture either paper pellets with adhered alkane or gelatine capsules, the correct frequency of dosing and the optimal timing of grab faecal sampling in relation to diurnal variation in alkane excretion [20]. Despite these setbacks results in sheep and cattle appear very promising [20, 24, 25, 29].

Controlled-release capsule (CRC) technology was first made available using $\mathrm{Cr}_{2} \mathrm{O}_{3}$, and was found to greatly reduce diurnal variation in marker excretion $[8,12]$. Recently CRC containing synthetic alkanes have been made commercially available for several categories of livestock. The device is administered once orally and is assumed to release intra-ruminally $\mathrm{C}_{32}$ and $\mathrm{C}_{36}$ at a steady rate. Few published data are available from alkane CRC. The technology has been employed with pastured Merino wethers [1, 11] and beef cattle [2, 14]. The objectives of this study were to assess the importance of possible effects on the accuracy of intake estimates in cows dosed with alkane CRC. These variables included feeding regimen (two levels of forage intake), day within faeces collection period, hour of faecal grab sampling and precision of the laboratory method.

\section{MATERIALS AND METHODS}

\subsection{Animals and diets}

Four multiparous Brown Swiss cows (average $611 \pm 25 \mathrm{~kg}$ ), two in early lactation $(33 \pm 2 \mathrm{~kg} /$ day milk) and two in late lactation (11 $\pm 2 \mathrm{~kg} /$ day milk) were tethered in individual stalls complete with slatted floor designed for digestibility trials. Cows were accustomed to these stalls where they were also milked. Forage intake was automatically weighed by computerised hoppers. The two early-lactating cows received diet 1 composed of 1:1 forage mix and concentrate (mean $10.4 \mathrm{~kg}$ concentrate $\mathrm{DM} /$ day) fed over 5 portions per day without refusals whereas the remaining two cows received the same forage mix ad libitum with no concentrate (diet 2). Feed nutrient and alkane 
Table I. Feed nutrient composition and alkane content.

\begin{tabular}{|c|c|c|}
\hline & Forage $^{1}$ & Concentrate $^{2}$ \\
\hline \multicolumn{3}{|l|}{ Nutrient content ( $\mathrm{g} / \mathrm{kg}$ DM) } \\
\hline Dry matter (DM) & 437 & 969 \\
\hline Organic matter & 884 & 929 \\
\hline Crude protein & 121 & 171 \\
\hline Crude fiber & 236 & 142 \\
\hline PDI (absorbable protein) ${ }^{3}$ & 79 & 122 \\
\hline NEL $(\mathrm{MJ} / \mathrm{kg} \mathrm{DM})^{3}$ & 5.8 & 6.4 \\
\hline \multicolumn{3}{|l|}{$n$-alkane content $(\mathrm{mg} / \mathrm{kg} D M)$} \\
\hline $\mathrm{C}_{31}$ & 121 & 8 \\
\hline $\mathrm{C}_{32}$ & 4 & 1 \\
\hline $\mathrm{C}_{33}^{32}$ & 44 & 2 \\
\hline $\mathrm{C}_{36}$ & not detected & not detected \\
\hline
\end{tabular}

${ }^{1}$ Forage mix of $51 \%$ grass silage, $39 \%$ maize silage and $10 \%$ hay on a DM basis.

${ }^{2}$ Diet 1 only.

${ }^{3}$ Estimated according to [10].

content is summarised in Table I. $\mathrm{C}_{31}$ and $\mathrm{C}_{33}$ alkanes were at low concentrations in the concentrate compared to forage. $\mathrm{C}_{32}$ concentration was low in both feedstuffs and $\mathrm{C}_{36}$ was virtually absent.

\subsection{Experimental procedure}

Controlled-release capsules (CRC, type MCM, Captec Ltd, Auckland, New Zealand) designed for 300-650 kg liveweight cattle were used. Capsules are routinely tested by the company who check the disappearance of the matrix length over time in rumen fistulated cattle. The expected mean release rates were 388.2 and $386.0 \mathrm{mg} /$ day for $\mathrm{C}_{32}$ and $\mathrm{C}_{36}$ respectively. The expected time-span at a constant release rate was $20 \pm 3$ days. Dosing of CRC was performed at 9 a.m. on day 1 using a length of rubberised tubing and plunger specifically designed to match the capsule diameter. The total faecal collection period lasted 7 days from days 8 to 14 , this being the recommended sampling window by the manufacturer. Urine separators were attached to each cow via velcrose and adhesive in order to divert urine from faeces.
Intake estimated from faecal alkane concentrations assumed a peak passage delay of alkane of $48 \mathrm{~h}$, this peak delay is typical for ruminants [26]. This was especially pertinent to the high fibre content of the forage mix fed (Tab. I) with possible longer residency in the rumen in comparison to many diets used in other studies where shorter passage delays were assumed. Therefore known intake values represent data from days 6-12 and recovery of alkanes were calculated from sampling days 8-14. Mean recovery of alkanes (Tab. II) were calculated as the difference of excreted alkane (over days 8-14) minus dietary intake over days 6-12 and for $\mathrm{C}_{32}$ and $\mathrm{C}_{36}$, minus stated capsule release rate. In Table III known intake from day 8 was related to faecal grab samples taken on day 10 .

Fresh forage and concentrate were sampled daily from days 6-12. Total faeces output was weighed and mixed for each cow every day at 9 a.m. Faeces were sampled from the total mix for between-day comparison and for pooling over the week. On day 10 , rectal grabs were additionally taken from all cows at 6.30 a.m., 1.30 p.m. and 8.30 p.m. to monitor within-day variation 
of alkane excretion in order to calculate the accuracy of spot sampling for daily feed intake estimation. Rectal grab samples were also taken at day 21 and 36 after CRC dosing in order to monitor capsule expire process. All forage and faeces samples destined for pooling were refrigerated then mixed and dried in a ventilated oven at $60{ }^{\circ} \mathrm{C}$ for $48 \mathrm{~h}$. All other samples were dried on the day of collection. Samples were permitted to stabilise with ambient humidity before reweighing and then milling through a $0.75 \mathrm{~mm}$ screen. Final dry matter determination and organic matter content of feed and faeces was made by ashing in a muffle furnace with steps at $105^{\circ} \mathrm{C}$ and $550{ }^{\circ} \mathrm{C}$ using automatic weight loss measurement (TGA 500, Leco corp, Michigan, USA). Feed samples were analysed for crude protein using Kjeldahl method and crude fibre content according to standard techniques [22].

\subsection{Alkane analysis}

Alkanes were analysed by direct saponification with some minor variations to the method outlined by Dove [3]. We used $1 \mathrm{~g}$ of oven-dried faeces and $2 \mathrm{~g}$ of either concentrate or oven-dried forage with a replicate extraction for each sample. $N$-heptane (extrapure, Merck) replaced $n$-hexane throughout extraction steps and final dilution $(1.5 \mathrm{ml})$ of the eluates for gas chromatography (GC) analysis as suggested by Vulich et al. [28]. Quantification of the alkanes was performed using a HP-6890 GC equipped with a flame ionisation detector (FID) and an adapter to fit megabore columns. The column used was a SPB-1 (Supelco, Buchs, Switzerland). Chromatographic conditions were the following: Carrier gas $\mathrm{H}_{2}$ at $10 \mathrm{ml} / \mathrm{min}$ constant flow; inlet temperature $300{ }^{\circ} \mathrm{C}$; oven programmed from $220^{\circ} \mathrm{C}$ (held for $2 \mathrm{~min}$ ) with $5{ }^{\circ} \mathrm{C} / \mathrm{min}$ to $250{ }^{\circ} \mathrm{C}, 4.5^{\circ} \mathrm{C} / \mathrm{min}$ to $277^{\circ} \mathrm{C}$ and $4{ }^{\circ} \mathrm{C} / \mathrm{min}$ to 297 (held for $1 \mathrm{~min}$ ); FID was set to $315^{\circ} \mathrm{C}$. Two injections per sample replicate were run. A mix of commercial alkanes (> 99\% pure, Fluka) spanning the spectrum from $\mathrm{C}_{24}-\mathrm{C}_{36}$ dissolved in heptane were frequently injected in order to monitor GC response. The average chromatogram area values from this mix were used to calculate correction factors relative to $\mathrm{C}_{34}$ which was used as an internal standard to adjust sample area values of the other alkanes.

\subsection{Calculations and statistical analyses}

Forage intake was calculated from the following formula given by Mayes et al. [20]:

$$
\begin{gathered}
\text { Herbage intake }=[F i / F j \times(D j+I c \times C j) \\
-I c \times C i] /(H i-F i / F j \times H j) .
\end{gathered}
$$

$\mathrm{Fi}, \mathrm{Ci}$ and $\mathrm{Hi}$ are respective concentrations $(\mathrm{mg} / \mathrm{kg} \mathrm{DM})$ of $\mathrm{C}_{31}$ or $\mathrm{C}_{33}$ in faeces, concentrate and forage mix. $F j, C j$ and $H j$ are respective concentrations $(\mathrm{mg} / \mathrm{kg} \mathrm{DM})$ of $\mathrm{C}_{32} . \mathrm{Dj}$ is the stated batch release rate for the CRC. Ic is the intake of concentrate $(\mathrm{kg} /$ day DM). Formulae for cows consuming forage only are the same omitting $\mathrm{Ci}, \mathrm{Cj}$ and Ic; estimates in Tables II and III and Figure 1 included either $\mathrm{C}_{31}: \mathrm{C}_{32}$ or $\mathrm{C}_{33}: \mathrm{C}_{32}$ ratios as indicated.

Statistical analyses were performed using SAS (version 6.12, SAS Institute Inc., Cary, $\mathrm{NC}$, USA). The difference ( $\pm \mathrm{kg} /$ day) of estimated to known intakes, the alkane recovery data and variation in faecal alkane concentrations and ratio options were analysed using a mixed model (method $=$ REML). Data ( $n=28$ observations) were analysed in turn with diet $(\alpha)$, day (b) and their interaction $\left(\alpha^{*} b\right)$ as fixed effects (model 1). The covariation within animals $\mathrm{V}\left(d_{i j}\right)$ was accounted for in an analysis of repeated measures, the optimal covariance structure for all data sets was found to be compound symmetry $\left(\operatorname{cov}\left(e_{i j k}\right)\right)$ with attention to Schwarz's Bayesian criterion as explained by Littell et al. [16]. The Bonferroni $t$ test was used to test the fixed effects.

$$
\begin{gathered}
\text { Model 1: } y_{i j k l}=\mu+\alpha_{i}+b_{k}+\left(\alpha^{*} b\right)_{i k} \\
+\mathrm{V}\left(d_{i j}\right)+\operatorname{cov}\left(e_{i j k l}\right) .
\end{gathered}
$$


The difference $( \pm \mathrm{kg} /$ day) of estimated to known intake from within-day grab samples for both ratio options ( $n=12$ observations) were analysed using model 1 , with day effect substituted for time effect.

Variation between replicate faecal alkane extractions was investigated to test 'repeatability' of the laboratory procedure and indicate how homogenous the samples were in respect to distribution of alkanes. The concentrations of alkanes in all faecal replicates $(n=88)$ were analysed in turn using sample number as a fixed effect $(\alpha)$ and the mean square (MS) results from the analysis of variance (model 2) were included in the repeatability formula [9]:

\[ \text { Model 2: } y_{i j}=\mu+\alpha_{i}+e_{i j} . \]
Repeatability $=\frac{\mathrm{s}^{2}(\text { sample })}{\mathrm{s}^{2}(\text { sample })+\mathrm{s}^{2}(\text { error })}$
with
$\mathrm{s}^{2}($ sample $)=\frac{\text { MS (sample })-\mathrm{MS} \text { (error) }}{n}$.

in order to assess the necessity of replicating faecal alkane extractions and injecting alkane extracts twice for gas chromatography. The contribution of diet, cow, replicate alkane extraction and extract injection to the total variation for faecal alkane concentrations was analysed within day $(n=16)$, specifying nested effects (model 3 ) using the 'nested' procedure in SAS. Levels tested were $\operatorname{diet}(\alpha)$, cow within $\operatorname{diet} d_{i}\left(\alpha_{i}\right)$, replicate within cow and diet $b_{k}\left(d_{j}\left(\alpha_{i}\right)\right)$ and injection within replicate, cow and $\operatorname{diet}\left(e_{i j k}\right)$.

$$
\begin{gathered}
\text { Model 3: } y_{i j k l}=\mu+\alpha_{i}+d_{j}\left(\alpha_{i}\right) \\
+b_{k}\left(d_{j}\left(\alpha_{i}\right)\right)+e_{i j k l}
\end{gathered}
$$

\section{RESULTS AND DISCUSSION}

\subsection{General accuracy of forage intake and digestibility estimates}

Known mean forage DM intake was $12.7 \mathrm{~kg}(10.4 \mathrm{~kg}$ in diet 1 and $15.1 \mathrm{~kg}$ in diet 2 ), and cows receiving diet 1 additionally consumed $10.4 \mathrm{~kg}$ concentrate DM without refusals. The average discrepancy of estimated forage intake to known intake from the pooled week samples was -0.05 and $-1.60 \mathrm{~kg} \mathrm{DM}$ for $\mathrm{C}_{33}: \mathrm{C}_{32}$ and $\mathrm{C}_{31}: \mathrm{C}_{32}$ respectively (not given in tables). The average discrepancy for the estimated mean intake of individual days to known intake was -0.03 and $-1.53 \mathrm{~kg}$ DM (Tab. II) for $\mathrm{C}_{33}: \mathrm{C}_{32}$ and $\mathrm{C}_{31}: \mathrm{C}_{32}$ respectively. Sampling on 5 days only from days 9-13 gave only moderately less precise estimates than sampling over the week with a mean discrepancy to known intake of $-0.39 \mathrm{~kg}$ DM. The high level of concentrate for diet 1 (50\% of total DMI) had no significant bias on the estimation of forage intake (Tabs. II and III; Fig. 1). The linear regressions including all daily estimates from both levels of forage intake had inclinations significantly different $(p<0.001)$ from the line of equality (Fig. 1) for both ratio options. The correlations between $\mathrm{C}_{31}: \mathrm{C}_{32}$ and $\mathrm{C}_{33}: \mathrm{C}_{32}$ estimates and corresponding known intake values when derived from data of both diets (28 observations) were $r=0.77$ and $r=0.72$, respectively. Pooled sample estimates were highly correlated to the linear regression (Fig. 1) regardless of calculation option, although inferences are limited due to the small number of observations $(n=4)$. The optimal time for spot faeces sampling was 6.30 a.m. (Tab. III) resulting in precise estimates for all cows when using $\mathrm{C}_{33}: \mathrm{C}_{32}$ giving an average difference to known intake of only $+0.05 \mathrm{~kg}$ DM. There were no significant time effects between grab sampling times. The present findings agree with Hameleers and Mayes [13].

The mean recovery rates of $\mathrm{C}_{33}$ and $\mathrm{C}_{32}$ alkanes were similar (0.85 and 0.87; Tab. II), and the ratio of these alkanes therefore resulted in overall accurate intake estimates. $\mathrm{C}_{31}$ had a lower recovery of 0.76 , so the ratio of $\mathrm{C}_{31}$ with $\mathrm{C}_{32}$ was imbalanced by 0.11 leading to an underestimation of actual intake by approximately the same magnitude (Tab. II). This is in agreement with previous findings by Dove and Mayes [5] and is also evident in Figure 1 where estimates 
Table II. Comparison of known intakes from days 6-12 and estimated herbage intakes and recovery rates of alkanes from faeces sampled on days 8-14 following administration of controlled-release capsules ${ }^{1}$.

\begin{tabular}{|c|c|c|c|c|c|c|}
\hline & \multirow[t]{2}{*}{ Mean } & \multirow[t]{2}{*}{ SEM } & \multicolumn{2}{|c|}{ Range } & \multirow[t]{2}{*}{ Difference $^{2}$} & \multirow[t]{2}{*}{ Day effect ${ }^{3}$} \\
\hline & & & $\min$ & $\max$ & & \\
\hline \multicolumn{7}{|l|}{ Herbage intake ( $k g$ DM/day) } \\
\hline Known intake & 12.70 & 0.52 & 8.28 & 17.49 & & $\mathrm{H} \mathrm{H}$ \\
\hline $\begin{array}{l}\text { Estimated intake by alkane ratios } \\
-\mathrm{C}_{33}: \mathrm{C}_{32} \\
-\mathrm{C}_{31}: \mathrm{C}_{32}\end{array}$ & $\begin{array}{l}12.67 \\
11.17\end{array}$ & $\begin{array}{l}0.51 \\
0.40\end{array}$ & $\begin{array}{l}7.60 \\
6.90\end{array}$ & $\begin{array}{l}20.28 \\
18.05\end{array}$ & $\begin{array}{l}-0.03 \\
-1.53\end{array}$ & $\begin{array}{c}\mathrm{H} \\
\mathrm{NS}\end{array}$ \\
\hline \multicolumn{7}{|l|}{ Recovery of alkanes (week mean) } \\
\hline $\mathrm{C}_{31}$ (faecal output/intake) & 0.76 & 0.02 & 0.51 & 0.92 & & $\mathrm{H}$ \\
\hline $\mathrm{C}_{33}$ (faecal output/intake) & 0.85 & 0.02 & 0.55 & 1.05 & & $\mathrm{H} \mathrm{H}$ \\
\hline $\mathrm{C}_{32}$ (faecal output/intake $)^{4}$ & 0.87 & 0.02 & 0.68 & 1.17 & & $\mathrm{H}$ \\
\hline $\mathrm{C}_{36}$ (faecal output/stated release) & 0.81 & 0.03 & 0.59 & 1.18 & & NS \\
\hline
\end{tabular}

${ }^{1}$ Diet effect and the interaction with time were non significant for the difference to known intake and recovery data.

${ }^{2}$ Mean difference to known intake.

${ }^{3}$ Significance of day effect: $\mathrm{H}$ at $P<0.05$ level, H H at $P<0.01$ level, NS non significant.

${ }^{4}$ Intake includes sum of herbage, concentrate alkane and stated release.

Table III. Comparison of known to estimated herbage intakes from faecal grab samples taken at different times on day 10 following administration of controlled release capsules.

\begin{tabular}{lcccc}
\hline Herbage intake (kg DM/day) & $\begin{array}{c}\text { With } \\
\text { concentrate }\end{array}$ & $\begin{array}{c}\text { Without } \\
\text { concentrate }\end{array}$ & Difference $^{2}$ & SEM \\
\hline Known intake & $10.35 \pm 0.18$ & $15.29 \pm 1.45$ & & \\
Estimated intake using $C_{33}: C_{32}$ ratio & & & & \\
$\quad$ Grab samples at 6.30 a.m. & $10.35 \pm 0.28$ & $15.38 \pm 0.80$ & +0.05 & 0.19 \\
$\quad$ Grab samples at 1.30 p.m. & $9.46 \pm 0.62$ & $18.48 \pm 4.25$ & +1.15 & 2.03 \\
$\quad$ Grab samples at 8.30 p.m. & $10.74 \pm 0.94$ & $17.25 \pm 2.22$ & +1.18 & 1.20 \\
Estimated intake using $C_{31}: C_{32}$ ratio & & & & \\
$\quad$ Grab samples at 6.30 a.m. & $9.06 \pm 0.34$ & $13.65 \pm 0.58$ & -1.46 & 0.28 \\
$\quad$ Grab samples at 1.30 p.m. & $8.26 \pm 0.72$ & $15.51 \pm 3.18$ & -0.93 & 1.50 \\
$\quad$ Grab samples at 8.30 p.m. & $8.84 \pm 0.12$ & $14.27 \pm 1.43$ & -1.26 & 0.85 \\
\hline
\end{tabular}

${ }^{1}$ Known intake of day 8.

${ }^{2}$ Diet and time effects and the interaction were non significant for the difference to known intake.

calculated from $\mathrm{C}_{31}: \mathrm{C}_{32}$ lay mostly to the left of the line of equality with estimates calculated by $\mathrm{C}_{33}: \mathrm{C}_{32}$ lying more evenly. When adjusted for recovery loss, the $\mathrm{C}_{31}: \mathrm{C}_{32}$ estimate was far more accurate $(-0.25 \mathrm{~kg}$ deviation from known intake). Alkane recovery results from the week pool faecal samples (not given in tables) had negligible differences (mean-0.02) to the mean of the individual day samples supporting the use of pooled samples as previously found [27]. Alkane markers, at least those differing 


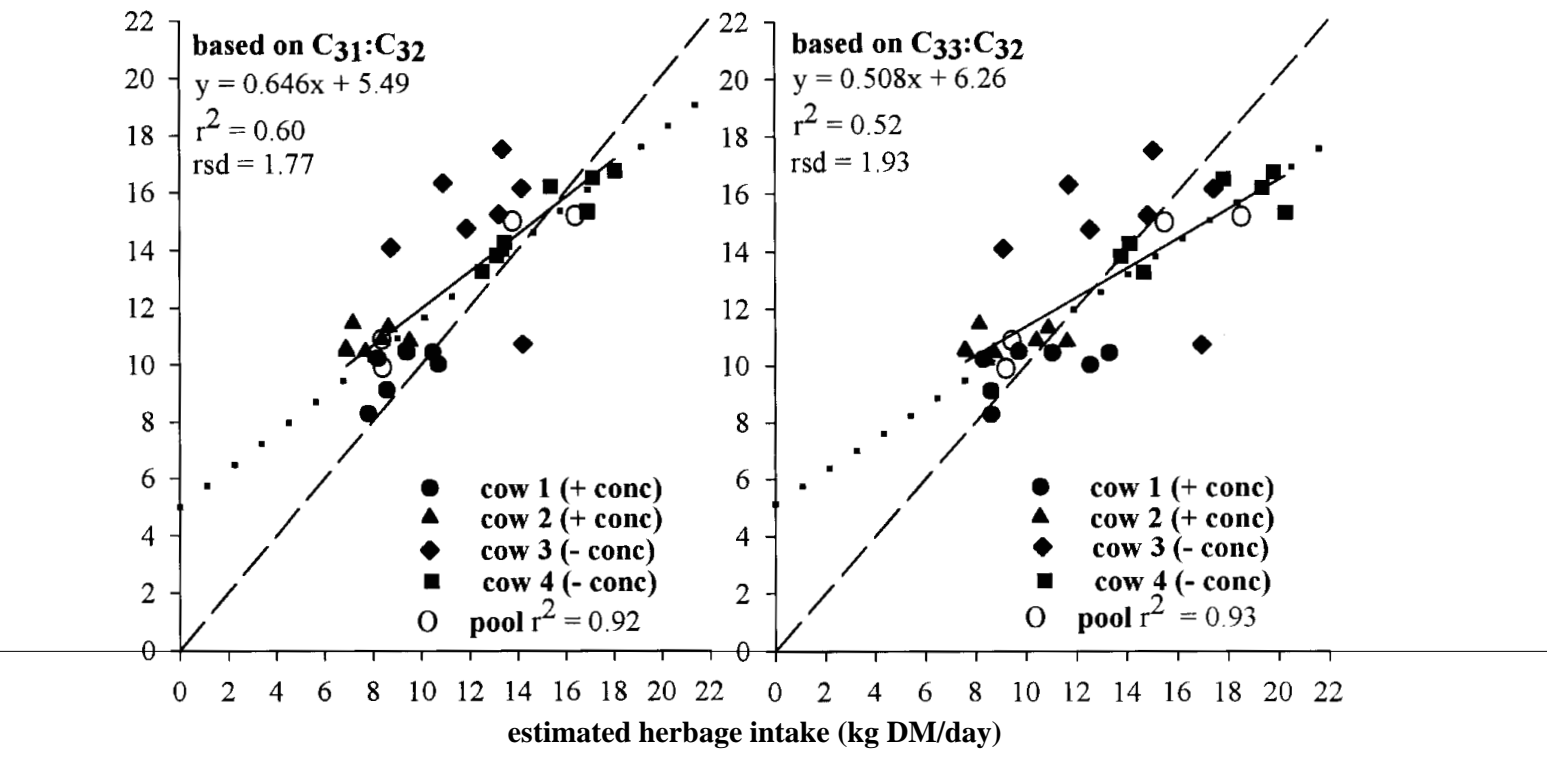

Figure 1. Comparison between known intakes (days 6-12) and estimated intakes from daily and pooled faecal samples (days 8-14) using $\mathrm{C}_{31}: \mathrm{C}_{32}$ (left) and $\mathrm{C}_{33}: \mathrm{C}_{32}$ (right). Solid line is the linear regression of daily estimates versus known intakes from both diets. Dotted line is the linear regression of pool estimates $(n=4)$ versus week mean known intakes. Pool $\mathrm{R}^{2}$ represents the correlation between the observations and the regression (dotted line). Dashed line represents line of equality.

only by one carbon atom in chain length, theoretically have similar recoveries and the bias due to incomplete recovery should automatically cancel in formulae [7, 20]. However a trend emerges for an increased recovery with increasing chain-length, which has been found to be more prominent in sheep $[7,19,20]$ and less so in cattle [4]. Recoveries of alkanes in this study compare favourably with other results using cattle [4], and no obvious trend for increased recovery with chain-length occurred (Tab. II). The recovery of $\mathrm{C}_{31}$ was too low for unadjusted comparison with $\mathrm{C}_{32}$. Mayes et al. [21] also found a lower recovery of 0.59 for $\mathrm{C}_{31}$ compared to 0.77 for $\mathrm{C}_{32}$ in cows. Herd et al. [14] and Dicker et al. [2] have used two designs of CRC with beef cattle with and without a large inclusion of barley. Herd et al. [14] discovered even lower recoveries of $\mathrm{C}_{31}$ in comparison to $\mathrm{C}_{32}$ (69\% vs. $93 \%$ ) causing underestimation of intake. The bet- ter estimates obtained using $\mathrm{C}_{33}: \mathrm{C}_{32}$ is thus related to their similar recoveries which is in agreement to the majority of findings elsewhere $[18,20,21,29]$. This appears to be of more importance than the low forage and concentrate content of $\mathrm{C}_{33}$ (44 and $2 \mathrm{mg} / \mathrm{kg}$ $\mathrm{DM}$ respectively) which is considered by some authors $[15,17]$ to be below the minimum threshold level $(<50 \mathrm{mg} / \mathrm{kg} \mathrm{DM})$ for use as an alkane marker. Dove et al. [6] similarly found that better estimates were possible using $\mathrm{C}_{33}: \mathrm{C}_{32}$ despite the low content of $\mathrm{C}_{33}$ in lucerne fed to sheep. Incomplete alkane recovery is probably mainly due to loss from the rumen itself [23]. Samples were dried at $60^{\circ} \mathrm{C}$ in this study so as not to cause any discriminant loss of alkanes through evaporation or through residue losses.

The mean determined organic matter (OM) digestibility for diets 1 and 2 was 
$0.72 \pm 0.03$ and $0.66 \pm 0.04$ respectively. When using the alkane technique with adjustment for alkane recovery loss $\left(\mathrm{C}_{33}: \mathrm{C}_{32}\right.$ for estimation of OM intake and $\mathrm{C}_{32}$ for $\mathrm{OM}$ excretion), the estimated $\mathrm{OM}$ digestibility $(0.72 \pm 0.02$ and $0.65 \pm 0.03)$ values calculated as an average of daily samples were almost exactly similar to determined values. $\mathrm{C}_{36}$ was not used for digestibility estimation owing to the unexpectedly high deviation of the mean between days for faecal $\mathrm{C}_{36}$ concentrations ( $\mathrm{Tab}$. IV), thus offering no advantage over $\mathrm{C}_{32}$ for this purpose.

\subsection{Alkane excretion and CRC expiry}

The significant diet effects for excretion of natural $n$-alkanes (Tab. IV) reflect the difference in forage intake between the diets.
There were no diet or day effects for the excretion of dosed alkanes, however there was a greater deviation of the mean for excretion of $\mathrm{C}_{36}$ as compared to $\mathrm{C}_{32}$ (Tab. IV). There was a significant day effect for actual forage intake (Tab. II) causing a concurrent between day effect for excretion of $\mathrm{C}_{33}$ which was marginally non-significant for $\mathrm{C}_{31}$ (Tab. IV). When calculating ratios with $\mathrm{C}_{32}$ these differences between ratios for day effects were far less marked.

Faecal grabs taken after 21 days indicated that three of the four capsules were still functioning at approximately the stated release rate. The mean faecal concentrations were $61 \mathrm{mg}$ for $\mathrm{C}_{32}$ and $56 \mathrm{mg} / \mathrm{kg} \mathrm{DM}$ of $\mathrm{C}_{36}$ and were similar to the mean values for dosed alkanes from the complete faecal collections within the recommended sampling window (day 8-14; Tab. IV). The fourth

Table IV. Between day variation of faecal concentration of natural and dosed $n$-alkanes (mg/kg DM) and ratio options 1 .

\begin{tabular}{|c|c|c|c|c|c|c|}
\hline \multirow{2}{*}{$\begin{array}{l}\text { Days after } \\
\text { dosing }^{2}\end{array}$} & \multicolumn{2}{|c|}{ Natural $n$-alkanes } & \multicolumn{2}{|c|}{ Dosed $n$-alkanes } & \multicolumn{2}{|c|}{ Ratio options } \\
\hline & $\mathrm{C}_{31}$ & $\mathrm{C}_{33}$ & $\mathrm{C}_{32}$ & $\mathrm{C}_{36}$ & $\mathrm{C}_{31}: \mathrm{C}_{32}$ & $\mathrm{C}_{33}: \mathrm{C}_{32}$ \\
\hline 8 & 187.5 & $73.1^{\mathrm{bc}}$ & 70.8 & 44.1 & $2.65^{\mathrm{b}}$ & $1.04^{\mathrm{b}}$ \\
\hline 9 & 186.8 & $71.8^{\mathrm{c}}$ & 61.8 & 62.6 & $3.06^{\mathrm{ab}}$ & $1.17^{\mathrm{ab}}$ \\
\hline 10 & 194.5 & $75.1^{\mathrm{bc}}$ & 69.5 & 51.7 & $2.78^{\mathrm{ab}}$ & $1.07^{\mathrm{b}}$ \\
\hline 11 & 196.2 & $83.9^{a}$ & 61.0 & 53.1 & $3.18^{\mathrm{ab}}$ & $1.36^{\mathrm{ab}}$ \\
\hline 12 & 186.5 & $83.4^{\mathrm{a}}$ & 55.6 & 45.3 & $3.34^{\mathrm{ab}}$ & $1.49^{\mathrm{a}}$ \\
\hline 13 & 193.8 & $82.0^{\mathrm{a}}$ & 57.3 & 50.4 & $3.38^{\mathrm{a}}$ & $1.43^{\mathrm{a}}$ \\
\hline 14 & 197.0 & $78.4^{\mathrm{ab}}$ & 61.5 & 60.2 & $3.29^{\mathrm{ab}}$ & $1.31^{\mathrm{ab}}$ \\
\hline \multicolumn{7}{|l|}{ Diet mean } \\
\hline+ concentrate & $142.2 \pm 10.3$ & $58.9 \pm 5.1$ & $59.1 \pm 6.7$ & $52.4 \pm 11.1$ & $2.43 \pm 0.32$ & $1.01 \pm 0.17$ \\
\hline - concentrate & $241.4 \pm 11.3$ & $97.6 \pm 6.3$ & $65.9 \pm 11.2$ & $52.6 \pm 14.7$ & $3.76 \pm 0.59$ & $1.52 \pm 0.28$ \\
\hline Total mean & $191.8 \pm 51.6$ & $78.2 \pm 20.5$ & $62.5 \pm 9.7$ & $52.5 \pm 12.8$ & $3.10 \pm 0.82$ & $1.27 \pm 0.34$ \\
\hline SEM & 9.8 & 3.9 & 1.8 & 2.4 & 0.15 & 0.06 \\
\hline \multicolumn{7}{|l|}{ Fixed effects ${ }^{3}$} \\
\hline Diet & $\mathrm{H} \mathrm{H}$ & $\mathrm{H} \mathrm{H}$ & NS & NS & NS & NS \\
\hline Day & NS & $\mathrm{H} \mathrm{H} \mathrm{H}$ & NS & NS & $\mathrm{H}$ & $\mathrm{H} \mathrm{H}$ \\
\hline Day $\times$ diet & NS & NS & NS & NS & NS & NS \\
\hline
\end{tabular}

\footnotetext{
${ }^{1}$ Intake of concentrate alkanes were subtracted from all data before analyses.

${ }^{2}$ Means between days carrying no common superscript differ at $P<0.05$ level.

${ }^{3}$ Significance of effect: $\mathrm{H}$ at $P<0.05$ level, $\mathrm{H} \mathrm{H}$ at $P<0.01$ level, $\mathrm{H} \mathrm{H} \mathrm{H}$ at $P<0.001$ level, NS non significant.
} 
capsule was suspected to be reaching expiry, with a faecal concentration of $37 \mathrm{mg}$ of $\mathrm{C}_{32}$ and $26 \mathrm{mg} / \mathrm{kg} \mathrm{DM}$ of $\mathrm{C}_{36}$ recovered in faeces from this cow. After 36 days all capsules had expired, however a small residual excretion was found in faeces indicated by a marginally detectable amount of $1.5 \mathrm{mg} / \mathrm{kg}$ DM of $\mathrm{C}_{36}$. As feeds were void of $\mathrm{C}_{36}$ this trace amount could only have originated from $\mathrm{CRC}$ possibly stored at remote ruminal sites.

\subsection{Repeatability of laboratory method}

The laboratory method proved to be accurate with results between replicates being highly repeatable; repeatabilities from faecal samples were $0.97,0.99$ and 0.83 for $\mathrm{C}_{31}, \mathrm{C}_{33}$ and $\mathrm{C}_{32}$ respectively. However $\mathrm{C}_{36}$ gave a poor repeatability of 0.29 . The exact same laboratory procedure adopted for this study has been previously tested in 166 faecal replicates from pastured cows resulting in high repeatabilities of $0.92,0.99,0.96$ and 0.83 for $\mathrm{C}_{31}, \mathrm{C}_{33}, \mathrm{C}_{32}$ and $\mathrm{C}_{36}$ respectively (unpublished results). It is therefore doubtful that the procedure itself caused the lower repeatability between replicates for dosed alkanes in the present study. The results of the within day 'nested' ANOVA showed that diet accounted for over $96 \%$ of the total variation of natural $n$-alkanes in faeces and less than $1 \%$ to variation between replicate extractions. However differences between replicates alone attributed to $67 \%$ and $15 \%$ of the total variation in faeces for $\mathrm{C}_{36}$ and $\mathrm{C}_{32}$ respectively. This identifies a marked reduction in the precision to extract faecal $\mathrm{C}_{36}$ over $\mathrm{C}_{32}$. This is possibly related to uneven distribution of dosed alkanes and in particular $\mathrm{C}_{36}$ in the initial milled samples. Dosed alkanes might associate with the liquid digesta phase [4] which would suggest that diets containing a significant amount of indigestible fibre (particulate phase) will result in a lower concentration of dosed alkanes in the faecal fibre fraction. It seems therefore fundamental to mill the dried faeces through a sufficiently small sized screen to distribute the fibre fraction evenly and create a homogenous end sample. This may justify using screens of $<0.75 \mathrm{~mm}$ contrary to the usual $1 \mathrm{~mm}$ screens. The proportion of the total variance attributed to the GC injections for all alkanes was $\leq 1 \%$. This justifies the running of only a single GC injection per replicate. However replicate extractions are still necessary as typically $8 \%$ of faecal samples in our studies required a further repeat due to differences $\geq 10 \%$ between replicates for alkane concentrations.

\section{CONCLUSION}

CRC technology proved to be a practical and precise way to dose alkane markers for experimental determination of forage intake in cows grab-sampled for a 7 day period. Reducing the number of faecal sampling days resulted in poorer estimates owing to the tendency for the technique to initially underestimate actual intake and to overestimate in the last days of the recommended faeces sampling window (day 8-14). However sampling on 5 days only from days 9-13 gave only a moderate reduction in precision of estimates. This may be of value for large scale research and warrants further investigation. Under the feeding conditions implemented in this study, the accuracy of the intake estimates tends to be higher if the cows are grab-sampled at 6.30 a.m. as compared with 1.30 p.m. or 8.30 p.m. The digestibility estimates based on $\mathrm{C}_{36}$ as an external marker are not satisfactory so far possibly due to a lower precision in extraction of this alkane as compared with the other dosed alkane. This study confirms that a single GC injection only per replicate is justifiable.

\section{ACKNOWLEDGEMENTS}

We wish to thank Bruno Jörg for constructing the dosing device used. We are grateful to Armon Fliri and Anton Felder for their assistance during the experiment at the ETH research station 
Chamau. We are also grateful to Beda Estermann for help given in the laboratory and Martine Steiger Burgos for preparation of the text. The project was carried out within the ETH poly project 'Sustainable Primary Production in the Alpine Region (PRIMALP)'.

\section{REFERENCES}

[1] Champion S.C., Robards G.E., Lindsay A.R., Friend M.A., Alkane technology estimates of summer and winter herbage intake of four speciality carpet wool breeds, Romneys and Merinos, Proc. N.Z. Soc. Anim. Prod. 55 (1995) 130-132.

[2] Dicker R.W., Herd R.M., Oddy V.H., Alkanes and controlled release devices for estimating intake of ryegrass by cattle, Proc. Nutr. Soc. Aust. 20 (1996) 107.

[3] Dove H., Using the $n$-alkanes of plant cuticular wax to estimate the species composition of herbage mixtures, Aust. J. Agric. Res. 43 (1992) 1711-1724.

[4] Dove H., Mayes R.W., The use of plant wax alkanes as marker substances in studies of the nutrition of herbivores: A review, Aust. J. Agric. Res. 42 (1991) 913-952.

[5] Dove H., Mayes R.W., Plant wax components: A new approach to estimating intake and diet composition in herbivores, J. Nutr. 126 (1996) 13-26.

[6] Dove H., Mayes R.W., Freer M., Using cuticular wax alkanes to estimate herbage intake in animals fed supplements, Ann. Zootech. 44 Suppl (1995) 237.

[7] Dove H., Mayes R.W., Freer M., Coombe J.B., Foot J.Z., Faecal recoveries of the alkanes of plant cuticular waxes in penned and in grazing sheep, Proc. XVI Int. Grassld. Congr., Nice, France, 1989, pp. 1093-1094.

[8] Ellis K.J., Laby R.H., Burns R.G., Continuous controlled-release administration of chromic oxide to sheep, Proc. Nutr. Soc. Aust. 6 (1981) 145.

[9] Essl A., Statistische Methoden in der Tierproduktion (Statistical methods in animal production), Österreichischer Agrarverlag, Wien, 1987.

[10] Forschungsanstalt für Viehwirtschaftliche Produktion, Fütterungsempfehlungen und Nährwerttabellen für Wiederkäuer (Recommended feeding standards and feed composition tables for ruminants) Landwirtschaftliche Lehrmittelzentrale, Zollikofen, Switzerland, 1994.

[11] Friend M.A., Robards G.E., Lindsay A.R., Champion S.C., The relative intake of three Merino strains under different grazing regimes estimated using alkane technology, Proc. N.Z. Soc. Anim. Prod. 55 (1995) 127-129.
[12] Furnival E.P., Ellis K.J., Pickering F.S., Evaluation of controlled release devices for administration of chromium sesquioxide using fistulated grazing sheep. II. Variation in rate of release from the device, Aust. J. Agric. Res. 41 (1990) 977-986.

[13] Hameleers A., Mayes R.W., The use of $n$-alkanes to estimate herbage intake and diet composition by dairy cows offered a perennial ryegrass/white clover mixture, Grass Forage Sci. 53 (1998) 164-169.

[14] Herd R.M., Williams T.M.J., Woodgate R., Ellis K.J., Oddy V.J., Using alkane technology to measure intake of a barley diet by cattle, Proc. Nutr. Soc. Aust. 20 (1996) 106.

[15] Laredo M.A., Simpson G.D., Minson D.J., Orpin C.J., The potential for using $n$-alkanes in tropical forages as a marker for the determination of dry matter by grazing ruminants, J. Agric. Sci. 117 (1991) 355-361.

[16] Littell R.C., Henry P.R., Ammerman C.B., Statistical analysis of repeated measures data using SAS procedures, J. Anim. Sci. 76 (1998) 1216-1231.

[17] Malossini F., Bovolenta S., Piasentier E., Piras C., Martillotti F., Comparison of $n$-alkanes and chromium oxide methods for estimating herbage intake by grazing dairy cows, Anim. Feed Sci. Tech. 61 (1996) 155-165.

[18] Mayes R.W., Dove H., Chen X.B., Guada J.A., Advances in the use of faecal and urinary markers for measuring diet composition, herbage intake and nutrient utilisation in herbivores, in: Journet M., Grenet E., Farce M-H., Thériez M., Demarquilly C. (Eds.), Recent developments in the nutrition of herbivores, Proc. IVth Int. Sym. Nutr. Herb., Inra, Paris, 1995, pp. 381-406.

[19] Mayes R.W., Lamb C.S., The possible use of $n$-alkanes in herbage as indigestible faecal markers, Proc. Nutr. Soc. 43 (1984) 39A

[20] Mayes R.W., Lamb C.S., Colgrove P.M., The use of dosed and herbage $n$-alkanes as markers for the determination of herbage intake, J. Agric. Sci. 107 (1986) 161-170.

[21] Mayes R.W., Wright I.A., Lamb C.S., McBean A., The use of long-chain $n$-alkanes as markers for estimating intake and digestibility of herbage in cattle, Anim. Prod. 42 (1986) 457.

[22] Naumann K., Bassler R., Die chemische Untersuchung von Futtermitteln, Methodenbuch, Vol. 3 (Methods for the chemical analysis of feedstuffs) VdLUFA-Verlag, Darmstadt, Germany, 1997.

[23] Ohajuruka O.A., Palmquist D.L., Evaluation of $n$-alkanes as digesta markers in dairy cows J. Anim. Sci. 69 (1991) 1726-1732.

[24] Piasentier E., Bovolenta S., Malossini F., Susmel P., Comparison of $n$-alkanes or chromium oxide methods for estimation of herbage intake by sheep, Small Ruminant Res. 18 (1995) 27-32. 
[25] Reeves M., Fulkerson W.J., Kellaway R.C., Dove H., A comparison of three techniques to determine the herbage intake of dairy cows grazing Kikuyu (Pennisetum clandestinum) pasture, Aust. J. Exp. Agric. 36 (1996) 23-30.

[26] Van Soest P.J., Digestive flow, in: Van Soest P.J. (Ed.), Nutritional ecology of the ruminant, Cornell University Press, 1994, pp. 371-385.

[27] Vulich S.A., Hanrahan J.P., Faecal sampling for the estimation of herbage intake using $n$-alkanes: evaluation of sample pooling and the use of rec- tal grab samples, J. Agric. Sci. 124 (1995) 79-86.

[28] Vulich S.A., Hanrahan J.P., Crowley B.A., Modification of the analytical procedures for the determination of herbage and faecal $n$-alkanes used in the estimation of herbage intake, J. Agric. Sci. 124 (1995) 71-77.

[29] Vulich S.A., O'Riordan E.G., Hanrahan J.P., Use of $n$-alkanes for the estimation of herbage intake in sheep: accuracy and precision of the estimates, J. Agric. Sci. 116 (1991) 319-323. 